\title{
THE OTHER MONTH EFFECT: SOME EVIDENCE FROM THE CENTRAL AND EASTERN EUROPEAN MARKETS*
}

\author{
Yi-Chieh WEN-Bin LI \\ (Received: 12 February 2014; revision received: 18 August 2014; \\ accepted: 8 October 2014)
}

\begin{abstract}
January returns on stock markets can be used as a barometer for the subsequent 11-month holding period returns as documented by Cooper et al. (2006). We examine this apparent anomaly and analyze the effects of other holding periods of 1,3, and 6 months in six Central and Eastern European transition economies from January 1991 through December 2013. Our results do not support the presence of the other January effect (OJE) in five of the six markets. Instead, the results reveal significant anomalies in non-January months and that such effects vary across markets. This latter evidence might reflect different characteristics in these economies, including diverse levels of market efficiency, local risk factors, and portfolio management among others. Furthermore, we construct a trading rule using the other month effect to illustrate the possibility of developing profitable investment strategies to earn abnormal returns.
\end{abstract}

Keywords: market efficiency, calendar anomalies, other January effect, other month effect

JEL classification index: G14

* We thank, without implicating, Ali F. Darrat and the two anonymous reviewers for many useful comments.

Yi-Chieh Wen, Lecturer of Continuing Education, The Chinese Culture University, Taiwan. E-mail: ycwinae@yahoo.com.tw

Bin $\boldsymbol{L i}$, corresponding author. Senior Lecturer at the Department of Accounting, Finance and Economics, Griffith Business School, Griffith University, Nathan, Queensland, Australia.

E-mail: b.li@griffith.edu.au 


\section{INTRODUCTION}

Numerous anomalies in equity markets have contradicted the validity of the efficient market hypothesis (EMH) of Fama (1970) and others. The January effect, a widely recognised calendar anomaly, indicates that stock returns in January are significantly greater than returns in the remaining 11 months of the year. Many empirical studies have documented the existence of the January effect in the US and international stock markets (e.g., Rozeff - Kinney 1976; Keim 1983; Ho 1990; Haugen - Jorion 1996; Easterday et al. 2009; Dzhabarov - Ziemba 2010). Other studies, however, either do not find the January effect, or they report anomalies in other months in different countries (e.g., Fountas - Segredakis 2002; Mehdian - Perry 2002; Gu 2003; Darrat et al. 2011).

In terms of the other January effect (OJE), positive (negative) returns in January can predict positive (negative) returns in the remaining 11 months of the year. Many practitioners and financial media refer to it as the "January Barometer" discussed by Hirsch in his Stock Trader's Almanac in 1974. The OJE has received increasing academic attention. Hensel - Ziemba (1995) find that positive returns in January convey a significant signal for the rest of the year in the US stock market. Cooper et al. (2006) also provide US evidence that January stock returns are a powerful predictor of market returns over the next 11 months of the year. Specifically, the 11-month holding period returns following positive January returns are more likely to be positive and higher than those 11 months following negative January returns. Cooper et al. (2010) suggest that the OJE can affect investors in making a profitable investment strategy. In particular, they argue that the best trading rule in the US stock market is to long stocks following positive January returns, and invest in T-bills after negative January returns.

In contrast, Brown - Juo (2006) find that negative returns in January can be viewed as a bearish predictor for the rest of the year, while positive returns in January have weaker predictability for the next 11 months. Stivers et al. (2009) show that the predictive power of the OJE in many countries (except the US) has declined over time. For many markets outside the US, Easton - Pinder (2007) and Marshall - Visaltanachoti (2010) do not support the conclusion of Cooper et al. (2006). Even for the US market, Darrat et al. (2013) report results contrary to Cooper et al. (2006) and further show stronger anomalies for non-January months, particularly February and September. Thus, many recent studies conclude that the OJE cannot be generalised to other stock markets due to the different market characteristics.

There has been an ongoing controversy regarding the existence of the OJE because of the lack of a plausible explanation empirically. For example, Cooper et al. (2006) investigate a number of potential causes of the OJE, including macro- 
economic variables, business cycle risk, investor sentiment, and the Presidential cycle in the US stock market. However, they find that the OJE cannot be attributed to these possible variables. Easton - Pinder (2007) find no evidence that different tax-year ends across countries can explain the OJE. Stivers et al. (2009) indicate three possible explanations for the OJE, including an internationally priced risk factor, a ubiquitous behavioural bias and a temporary anomaly. In a more recent study, Chen - Daves (2013) use the Index of Consumer Sentiment (ICS, a proxy for market returns) to explore the predictability of January returns in the US market. They show that January ICS change seems to affect the OJE when explaining the returns over the next 11-month returns.

Previous research provides very little evidence of the other January/month effect in the Central and Eastern European (CEE) stock markets. There are only a very limited number of related studies that examine the calendar effects in these transition economies. For example, Tonchev - Kim (2004) examine calendar effects in three Eastern European countries (Czech Republic, Slovakia, and Slovenia) and find little evidence of anomalies in these markets. Asteriou Kavetsos (2006) explore seasonal effects of eight transition economies in Europe and report return patterns of the January effect. However, the CEE countries have made significant economic and political transformations through their accession to the European Union towards integration with the world economy. The degree of market efficiency in transition economies has a major impact on the profitability of trading strategies or the predictability of market returns. Furthermore, stock market anomalies have important practical implications for a wide range of market participants, including portfolio managers and individual investors. Contrary to the EMH, informed investors can exploit the anomalous pattern to earn a risk-free profit by predicting the behaviour of prices. Nevertheless, since many alleged anomalies are market-specific, it is important to test each market for the existence of these anomalies.

In this paper, we examine the other month anomaly (including the OJE) in CEE markets using data from January 1991 to December 2013. We also extend our analysis to other holding period returns following non-January months, which we call the "other month" effect. Furthermore, we examine the effect for holding periods of $1,3,6$, and 11 months. Our results do not generally support the presence of the OJE (over the holding periods of 1, 3, 6, and 11 months) on the CEE markets (the only exception is Slovakia) as the holding period returns following positive January returns are significantly larger than those following negative January returns. In contrast, we find the other month effect for months other than January, though the evidence varies across markets. On the other hand, we develop a trading rule based on our findings that show profitable investment strategies on the other month effects. More specifically, we consider positive (or nega- 
tive) return in the conditioning months to long (or short) market for subsequent holding periods. We create six visual graphs to compare the accumulated wealth of $\$ 1$ investments at the beginning of the sample period on the optimal portfolio $v s$. the buy-and-hold market portfolio for each country. We show that the optimal portfolio can be implemented by investors to earn abnormal returns.

Our paper makes three primary contributions. First, we contribute to the literature on the other January/month effect and focus on transition economies. Easton - Pinder (2007) examine the other month effect in international markets including the Czech Republic, Hungary, and Poland. However, their paper only uses 11-month holding period returns, while we explore the case for 1-, 3-, and 6-month holding period returns. Further, our sample also includes three other transition economies (Estonia, Romania, and Slovakia). Second, although the January barometer seems absent in the CEE stock markets, our results can help investors achieve superior returns by considering the "other months" returns instead of the "January" effect. Third, we construct a trading rule using the other month effect for each CEE country, and then we compare the performance of the optimal portfolio to the buy-and-hold market portfolio. Our results provide market participants with a signal to formulate their best trading strategies.

The remainder of this paper is organised as follows. Section 2 describes the data, while Section 3 outlines the methodology. Section 4 presents the empirical results and Section 5 concludes the paper.

\section{DATA DESCRIPTION}

We collect monthly stock return indices from January 1991 to December 2013 which represents the earliest coverage in DataStream for six transition economies of CEE. Our data comprise local stock indices of the Czech Republic (PX), Estonia (TALSE), Hungary (BUX), Poland (WIG), Romania (BET), and Slovakia (SAX16). These stock market indices are transformed into monthly rates of returns. The sample starting date varies across different markets. For example, the sample for Hungary starts from January1991, while for Romania it is September 1997. Table 1 provides details on the sample starting date for each market.

Table 1 also reports the summary statistics for monthly market returns. The lowest mean returns over the entire period is registered for June in the Czech Republic (-0.026), for September in Estonia (-0.041) and Hungary $(-0.014)$; for June in Poland (-0.026), August in Romania (-0.016), and for April in Slovakia $(-0.030)$. The highest mean returns are registered for July in the Czech Republic (0.032); for January in Estonia (0.065), Hungary (0.051), and Romania (0.056); for July and December in Poland (0.040); and for February in Slovakia (0.050). 
Table 1. Summary statistics of monthly stock returns

\begin{tabular}{|c|c|c|c|c|c|c|c|c|c|c|}
\hline & 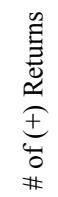 & 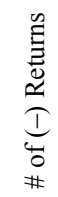 & 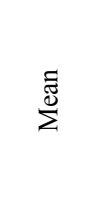 & $\begin{array}{l}\dot{0} \\
\stackrel{0}{0} \\
\dot{D}\end{array}$ & 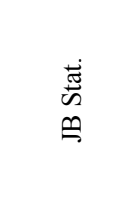 & 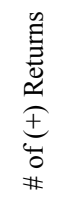 & 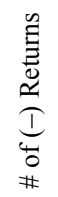 & $\sum_{\Sigma}^{\text {चี }}$ & $\begin{array}{l}\dot{0} \\
\text { Dे } \\
\dot{\vec{D}} \\
\dot{\omega}\end{array}$ & 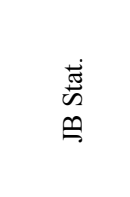 \\
\hline \multicolumn{6}{|c|}{ Czech Republic (April 1994-) } & \multicolumn{5}{|c|}{ Estonia (June 1996-) } \\
\hline January & 14 & 5 & 0.008 & 0.078 & $5.62 *$ & 13 & 4 & 0.065 & 0.109 & $12.82 * * *$ \\
\hline February & 11 & 8 & 0.006 & 0.084 & 1.77 & 10 & 7 & 0.010 & 0.100 & 0.53 \\
\hline March & 10 & 9 & 0.012 & 0.070 & 0.05 & 13 & 4 & 0.050 & 0.076 & 4.33 \\
\hline April & 10 & 10 & 0.007 & 0.065 & 2.45 & 11 & 6 & 0.004 & 0.053 & 0.98 \\
\hline May & 8 & 12 & -0.017 & 0.084 & 3.86 & 4 & 13 & -0.032 & 0.104 & $23.56 * * *$ \\
\hline June & 8 & 12 & -0.026 & 0.053 & 0.96 & 6 & 12 & -0.020 & 0.071 & $8.16^{* *}$ \\
\hline July & 14 & 6 & 0.032 & 0.055 & 2.11 & 13 & 5 & 0.021 & 0.073 & $38.45^{* * *}$ \\
\hline August & 13 & 7 & 0.002 & 0.081 & $38.81^{* * *}$ & 14 & 4 & 0.049 & 0.108 & $12.16^{* * *}$ \\
\hline September & 7 & 13 & -0.022 & 0.065 & $8.46^{* *}$ & 6 & 12 & -0.041 & 0.113 & $18.04 * * *$ \\
\hline October & 10 & 10 & -0.010 & 0.093 & $37.46^{* * *}$ & 9 & 9 & -0.024 & 0.112 & $23.61 * * *$ \\
\hline November & 9 & 11 & -0.020 & 0.069 & $7.59 * *$ & 11 & 7 & 0.004 & 0.148 & $25.72 * * *$ \\
\hline December & 16 & 4 & 0.028 & 0.044 & $13.29 * * *$ & 12 & 6 & 0.039 & 0.078 & 0.15 \\
\hline ALL & 130 & 107 & 0.000 & 0.072 & $81.52 * * *$ & 122 & 89 & 0.010 & 0.102 & $192.59 * * *$ \\
\hline \multicolumn{6}{|c|}{ Hungary (January 1991-) } & \multicolumn{5}{|c|}{ Poland (April 1991-) } \\
\hline January & 16 & 7 & 0.051 & 0.148 & $7.21^{* *}$ & 13 & 9 & 0.038 & 0.122 & 2.46 \\
\hline February & 12 & 11 & -0.002 & 0.074 & 0.34 & 12 & 10 & 0.017 & 0.084 & 0.19 \\
\hline March & 12 & 11 & 0.012 & 0.056 & 0.60 & 10 & 12 & 0.000 & 0.096 & $47.21 * * *$ \\
\hline April & 17 & 6 & 0.028 & 0.070 & 1.57 & 14 & 9 & 0.030 & 0.134 & $6.60 * *$ \\
\hline May & 13 & 10 & -0.008 & 0.082 & 0.87 & 12 & 11 & 0.025 & 0.162 & $329.56 * * *$ \\
\hline June & 13 & 10 & 0.004 & 0.072 & 1.21 & 12 & 11 & -0.026 & 0.115 & $56.14 * * *$ \\
\hline July & 15 & 8 & 0.028 & 0.071 & 0.35 & 13 & 10 & 0.040 & 0.098 & $7.07 * *$ \\
\hline August & 13 & 10 & 0.003 & 0.130 & $46.23 * * *$ & 13 & 10 & 0.012 & 0.131 & $26.69 * * *$ \\
\hline September & 12 & 11 & -0.014 & 0.070 & 2.23 & 11 & 12 & -0.018 & 0.080 & 2.30 \\
\hline October & 14 & 9 & -0.002 & 0.094 & $59.55^{* * *}$ & 15 & 8 & 0.014 & 0.126 & 0.98 \\
\hline November & 11 & 12 & -0.01 & 0.067 & 0.40 & 15 & 8 & 0.003 & 0.053 & 0.77 \\
\hline December & 16 & 7 & 0.035 & 0.064 & 3.78 & 16 & 7 & 0.040 & 0.083 & $64.48 * * *$ \\
\hline ALL & 164 & 112 & 0.011 & 0.088 & $349.16^{* * *}$ & 156 & 117 & 0.015 & 0.111 & $832.52 * * *$ \\
\hline
\end{tabular}


Table 1. continued

\begin{tabular}{|c|c|c|c|c|c|c|c|c|c|c|}
\hline & 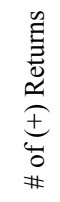 & 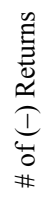 & 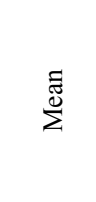 & 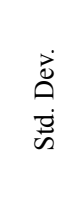 & 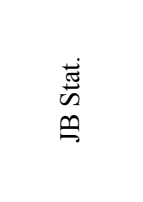 & 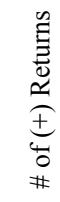 & 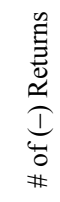 & 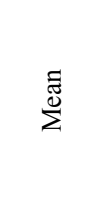 & 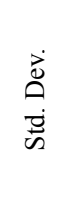 & 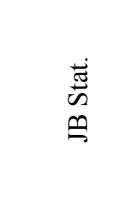 \\
\hline & \multicolumn{5}{|c|}{ Romania (September 1997-) } & \multicolumn{5}{|c|}{ Slovakia (September 1993-) } \\
\hline January & 13 & 3 & 0.056 & 0.152 & 2.85 & 8 & 12 & 0.010 & 0.132 & $150.28 * * *$ \\
\hline February & 10 & 6 & 0.021 & 0.065 & $21.63 * * *$ & 8 & 12 & 0.050 & 0.185 & $164.14 * * *$ \\
\hline March & 6 & 10 & -0.005 & 0.106 & 0.71 & 14 & 6 & 0.006 & 0.045 & 0.92 \\
\hline April & 8 & 8 & 0.017 & 0.109 & $14.99 * * *$ & 7 & 13 & -0.030 & 0.092 & $106.14 * * *$ \\
\hline May & 8 & 8 & -0.003 & 0.108 & 0.01 & 9 & 11 & -0.025 & 0.078 & 1.72 \\
\hline June & 9 & 7 & 0.019 & 0.085 & 4.07 & 10 & 10 & -0.007 & 0.052 & $6.04 * *$ \\
\hline July & 12 & 4 & 0.024 & 0.074 & 1.10 & 14 & 6 & 0.009 & 0.049 & $5.38^{*}$ \\
\hline August & 9 & 7 & -0.016 & 0.145 & $19.98^{* * *}$ & 16 & 4 & 0.026 & 0.035 & 0.64 \\
\hline September & 9 & 8 & -0.014 & 0.104 & 1.57 & 10 & 11 & -0.006 & 0.052 & $5.84 * *$ \\
\hline October & 12 & 5 & 0.005 & 0.113 & $109.97 * * *$ & 6 & 15 & -0.016 & 0.066 & $9.96 * *$ \\
\hline November & 8 & 9 & -0.011 & 0.117 & 4.15 & 10 & 11 & -0.008 & 0.085 & $8.31 * *$ \\
\hline December & 11 & 6 & 0.022 & 0.060 & 2.06 & 17 & 4 & 0.024 & 0.050 & 0.18 \\
\hline ALL & 115 & 81 & 0.009 & 0.106 & $91.23 * * *$ & 129 & 115 & 0.003 & 0.088 & $8286.39 * * *$ \\
\hline
\end{tabular}

Notes: All returns are in percentages. The highest and lowest mean returns over the entire period are denoted in bold. $* * * * *$ and $*$ indicate statistical significance at the $1 \%, 5 \%$ and $10 \%$ levels, respectively. All samples end in December 2013.

January scores the highest return and also generally displays the lowest standard deviations. The number of positive returns is greater than the number of negative returns for Hungary and Poland only. In unison with the mean/standard deviation statistics, December in the Czech Republic, Poland, and Slovakia has the largest number of positive returns and the lowest number of negative returns. The Jarque-Bera test suggests that the monthly returns are not normally distributed.

\section{METHODOLOGY}

To test the mean differences, we follow Darrat et al. (2013) and use $t$-test statistics. We examine the other month effect by comparing the differences between the average of accumulated $k$-month returns following positive conditioning months and the average of accumulated $k$-month returns following negative conditioning months, where the conditioning months range from January to December. For 
example, if it is January, we test the OJE. If it is December, we test the other December effect, etc. The holding period $k$ includes $1,3,6$, and 11 months.

The means test here is the same as the linear regression used by Cooper et al. (2006), where the accumulated 11-month returns are regressed on a dummy variable which is equal to one when the January return is positive and zero otherwise. They also employ a randomised bootstrap procedure whose results are essentially the same as those from the simple means test. For brevity, we confine our attention to the results from simple means tests.

\section{EMPIRICAL RESULTS}

\subsection{The other January/month effect}

Table 2 presents the other month anomalies for six CEE transition economies from January 1991 through December 2013. We report the mean and the standard deviation of accumulated $k$-month market returns following any positive/negative return in any of the 12 conditioning months. We also provide the number of positive and negative conditioning months. The holding period $k$ varies over 1, 3, 6 , and 11 months. To test the other month effect, we provide the spread between accumulated $k$-month market returns following both positive and negative returns along with their associated standard errors. For brevity, we only report the results for the conditioning months with any significant coefficient estimate in Table 2.

Panel $A$ in Table 2 shows that the "other January" effect does not exist in the Czech Republic. This finding is contrary to the evidence of Cooper et al. (2006) for the US market. Results in Panel A reveal that returns following positive returns in March, April, and December are significantly larger than those following negative returns in March, April, and December for holding periods of 1 and 3 months. The 11-month holding period returns following positive returns in November are greater than those following negative November returns by more than $20 \%$ per annum. This suggests that there are some other month effects in the Czech Republic.

Panel $B$ reports results for Estonia. The evidence there suggests that there are other April and other November effects. Returns subsequent to positive April (or November) returns are much larger than those subsequent to negative April (or November) returns for most holding periods. The magnitude is quite large at around $70 \%$ per annum. By contrast, returns following positive returns in January are higher than those following negative returns in January only for the holding period of 3 months. 


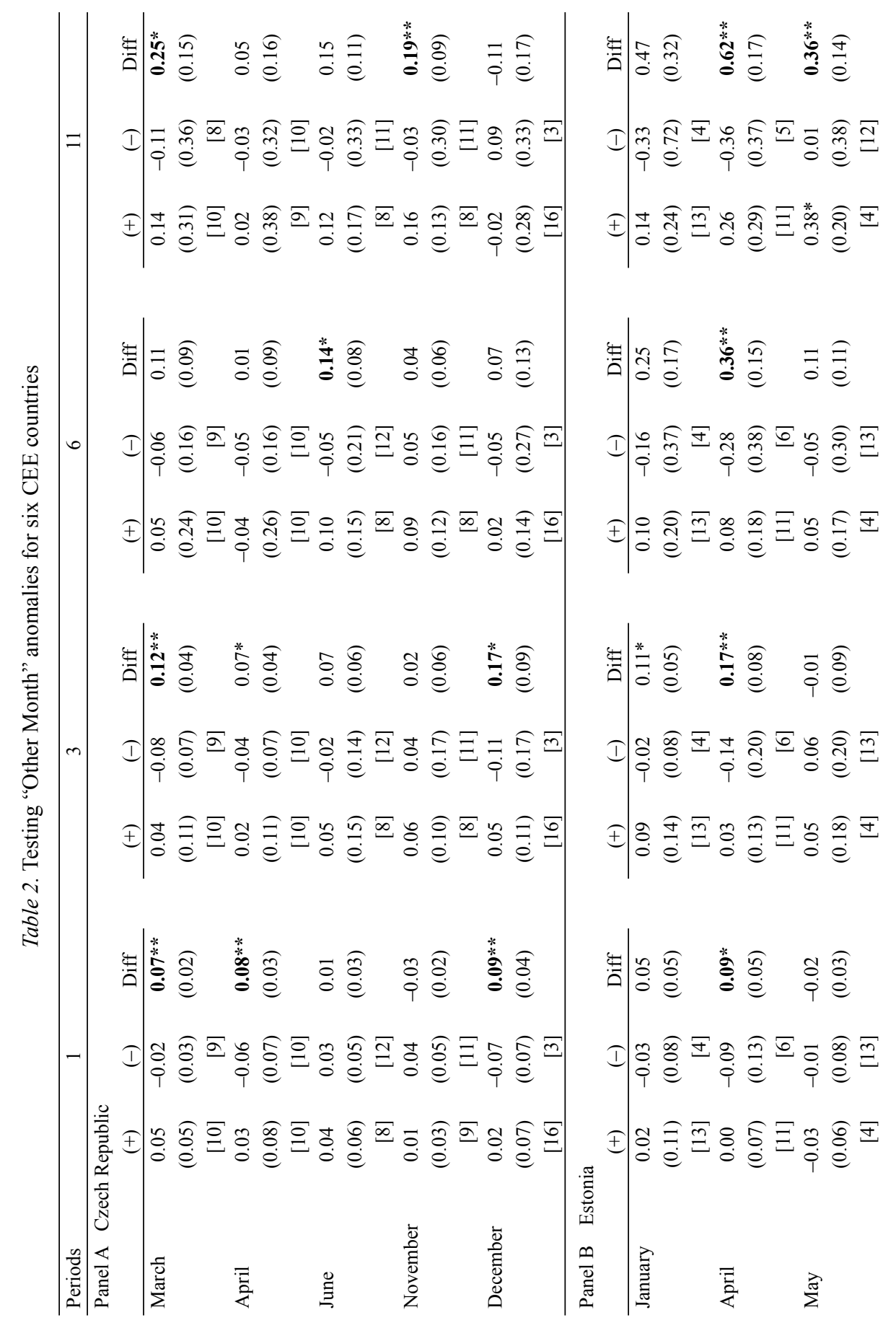




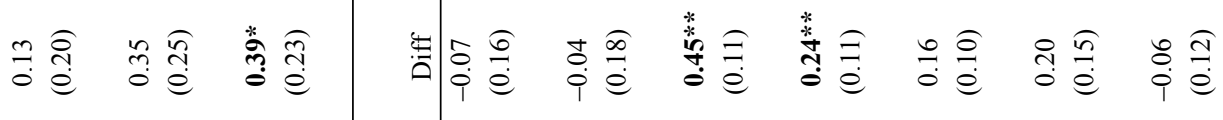

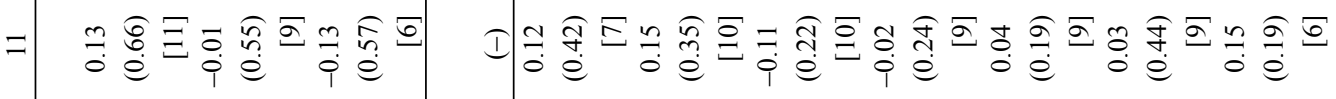

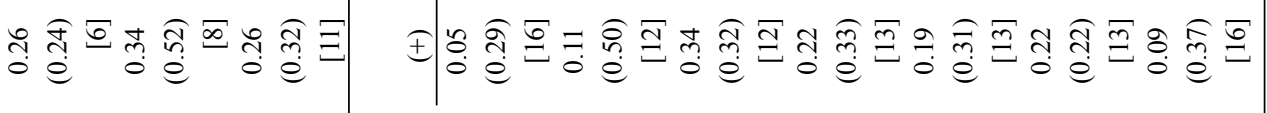

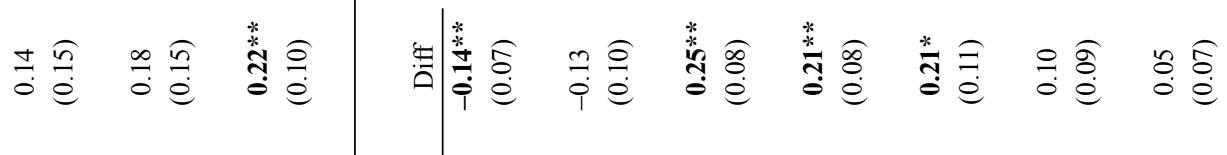

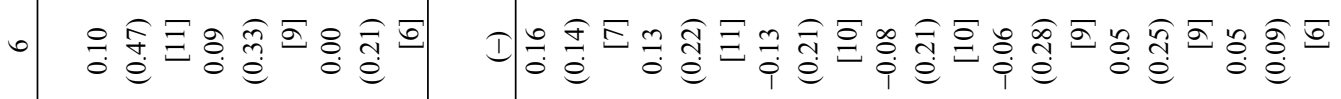

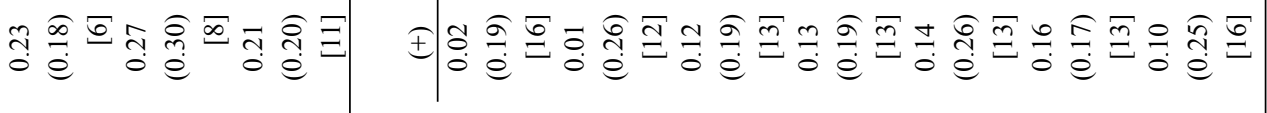

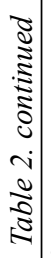

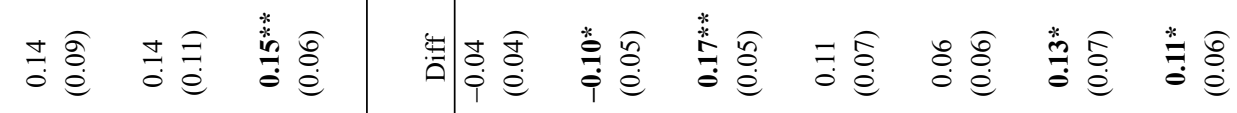

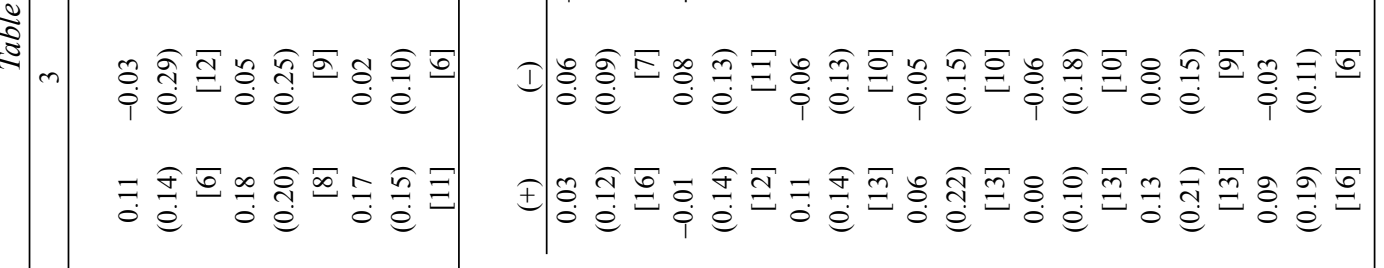

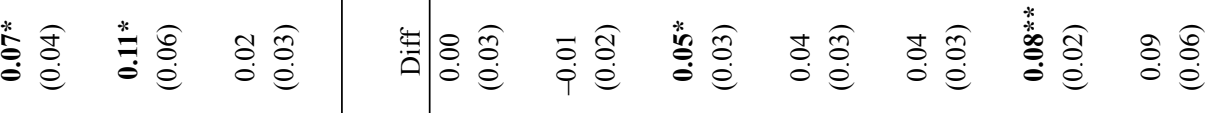

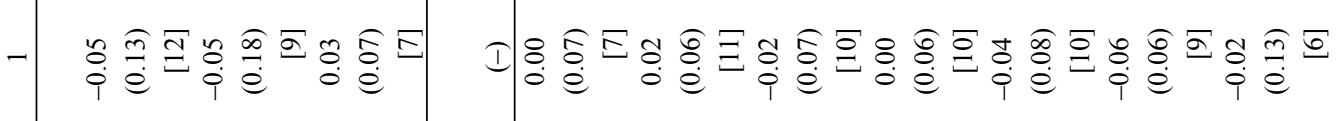

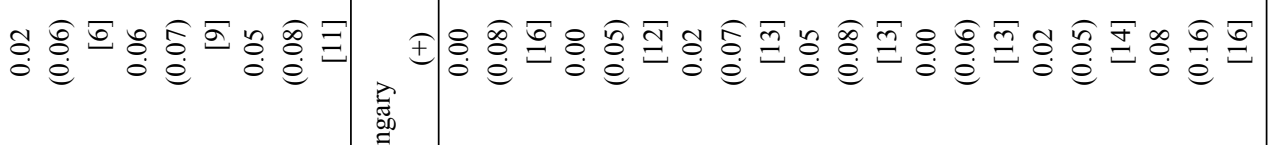

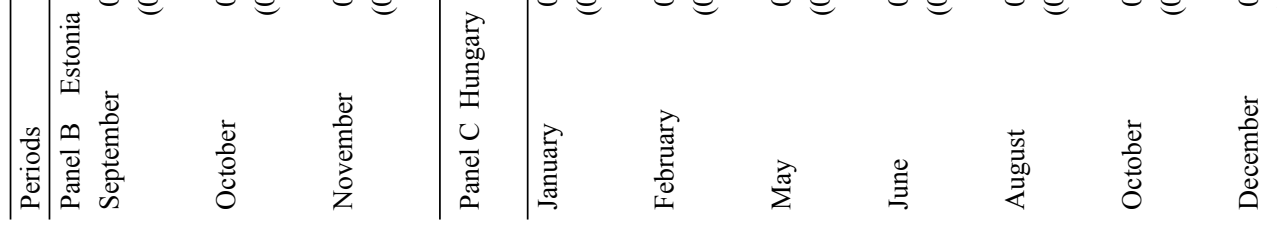




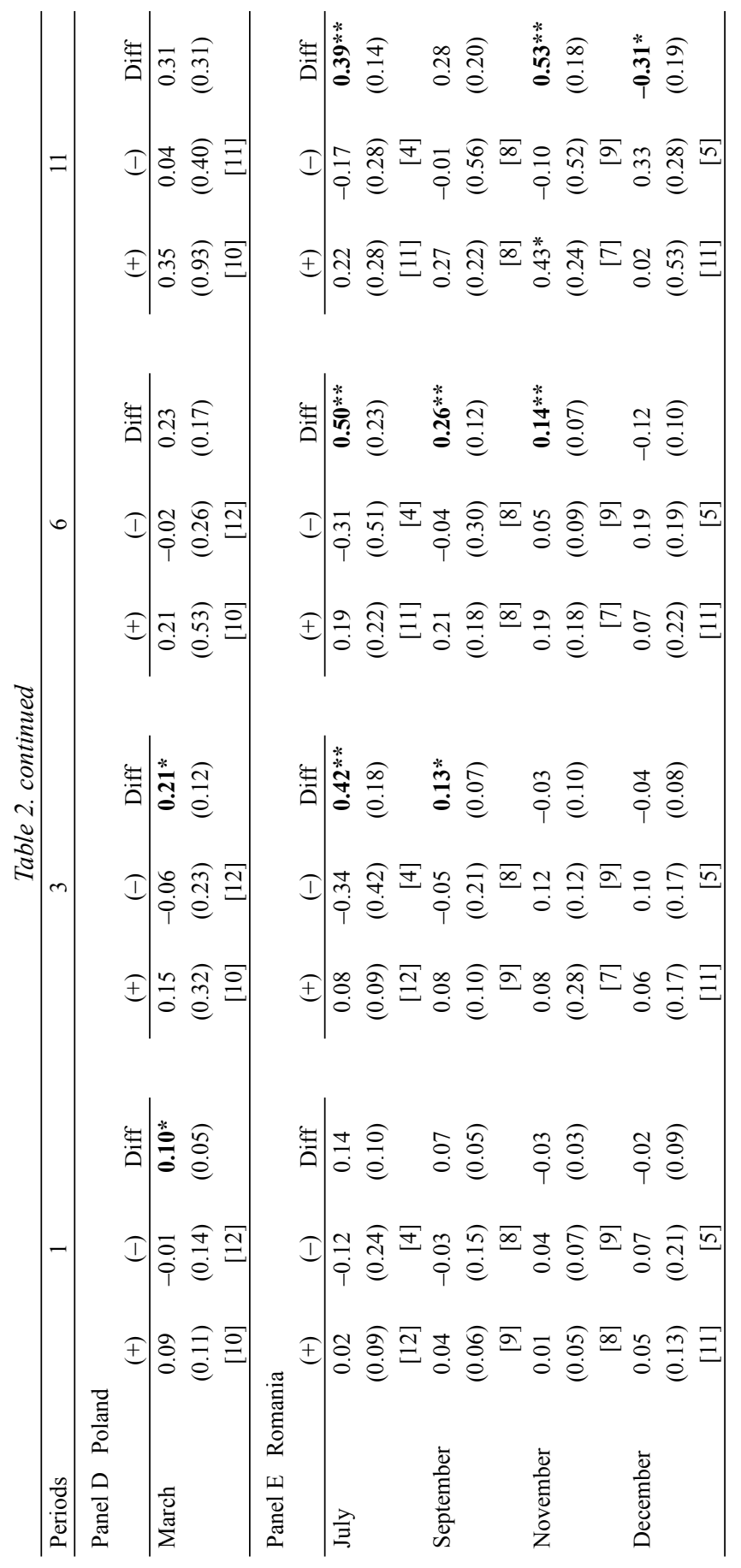




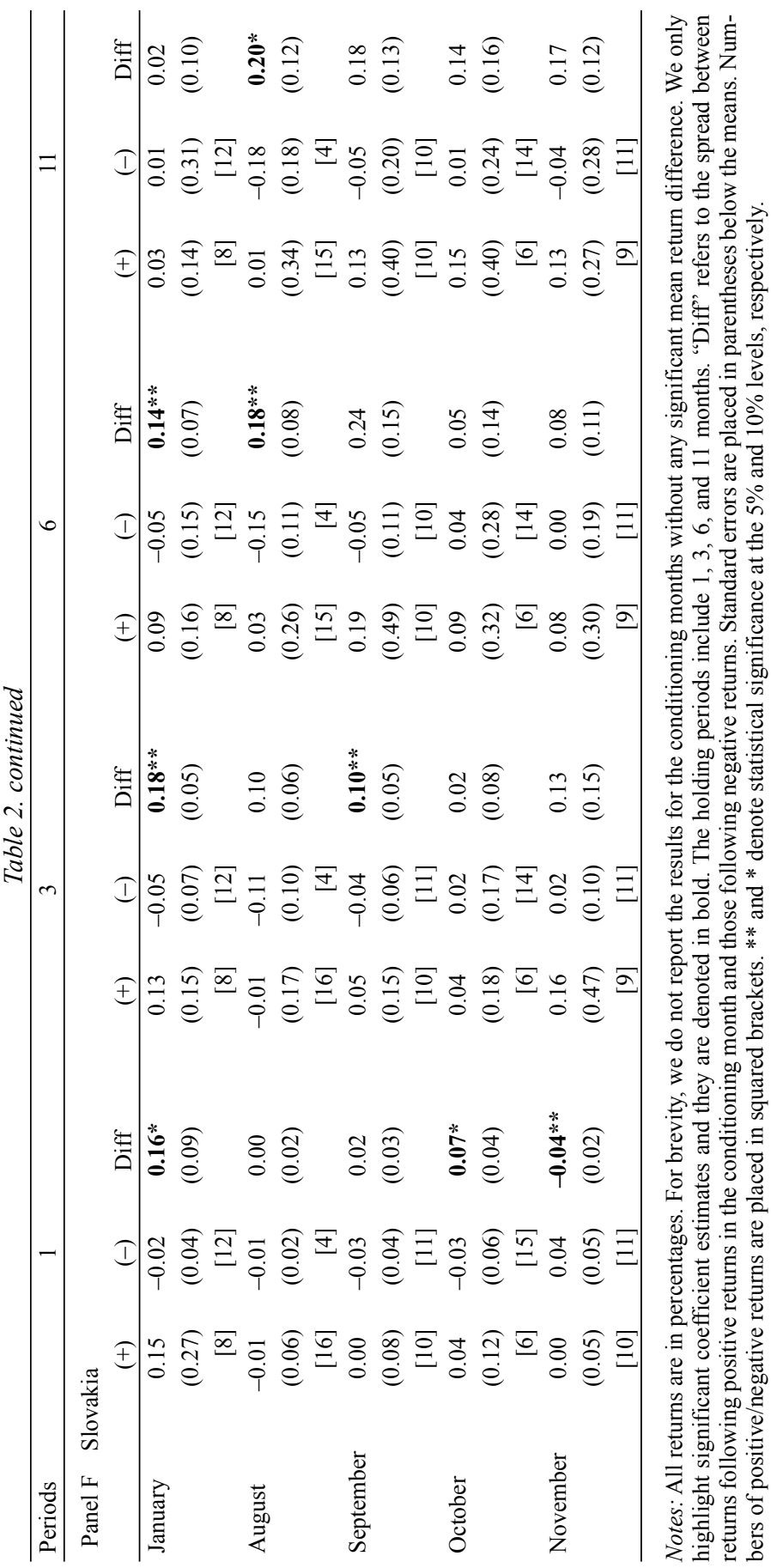


Panel $C$ for Hungary indicates the absence of the OJE similar to the results of Easton - Pinder (2007). Instead, 6-month holding period returns following positive January returns are, on average, statistically lower than those following negative January returns. However, there are other month effects for May (for all the holding periods) and June (for 6- and 11-month holding periods).

Similarly to the result for Hungary, the OJE does not exist for Poland either as shown in Panel D. Easton - Pinder (2007) also fail to find the OJE for Poland. The 1- and 3-month holding period returns following positive March returns are larger than those following negative March returns, but only at the $10 \%$ level of significance.

Panel $E$ for Romania also suggests no OJE. However, there is some evidence of the other July effect (for 3- to 11-month holding periods), other September effect (for 3- and 6-month holding periods only), and other November effect (for 6- and 11-month holding periods only).

However, the results in Panel $F$ for Slovakia support the presence of the OJE. Holding period returns following positive January returns are statistically larger than those following negative January returns, except perhaps for the 11-month holding period. For other conditioning months, the results are mixed. For example, 6- and 11-month accumulated returns following positive August returns are larger, on average, than those following negative August returns. By contrast, the 1 -month returns following positive November returns are $4 \%$ lower than those following negative November returns, indicating that there is a reversal in the next month following November.

\subsection{Trading strategy using the other month effect}

As mentioned earlier, Cooper et al. (2010) indicate the best trading rule using the OJE in the US stock market. That is, investors long stocks following positive January returns and invest in T-bills after negative January returns. They point out that the cumulative wealth over a long time period can provide useful information on alternative trading strategies to investors. Marshall - Visaltanachoti (2010) also consider whether the OJE can be implemented by investors to earn abnormal returns. We thus also explore the implications of the "other month" effect for potential profitable investment strategies.

We construct investment strategies on the other month effects. For comparability across markets, we start our sample over the period 1997 to 2013 for all trading strategies, while risk-free rates (3-month short interest rate) and stock returns for Romania are available until after September 1997. The benchmark is the buy-and-hold market portfolio in each market. By taking into consideration the 
other month effect which shows the most significant difference between positive and negative returns after the conditioning month, our optimal strategy for each country can be formulated as follows:

(1) For the Czech Republic, we use the March return as the conditioning return and 11-month holding period. This is because Panel A of Table 2 shows that the 11-month holding period returns following positive March returns are, on average, statistically larger than those following negative March returns by $25 \%$, which is the largest among all the strategies. Our optimal strategy for the Czech Republic is as follows: if March return is positive (negative), we long (short) the market portfolio from April until next February; we hold the risk-free asset in March.

(2) For Estonia, we use April as the conditioning month. If April return is positive (negative), we long (short) the market portfolio for the next 11 months and hold the risk-free asset in April.

(3) For Hungary, we use May returns. If May return is positive (negative), we long (short) the market portfolio for the subsequent 11 months and hold the risk-free asset in May.

(4) For Poland, we use March returns. If March return is positive (negative), we long (short) the market portfolio for April through to June (3 months) and hold the risk-free asset for July through to next March.

(5) For Romania, we use November returns. If November return is positive (negative), we long (short) the market portfolio for the subsequent 11 months and hold the risk-free asset in November.

(6) For Slovakia, we use August returns. If August is positive (negative), we long (short) the market portfolio for the next 11 months and hold the risk-free asset in August.

We thus obtain 6 time-series returns of the optimal portfolios and the buy-andhold (B\&H) market portfolios from 1997 to 2013. In Figure 1, we plot 6 graphs to compare the accumulated wealth of $\$ 1$ investments at the beginning of the sample period for two portfolios over the whole period in each country. Figure 1 clearly demonstrates that the cumulative wealth (at the end of the period) on our optimal portfolios is higher than the market portfolio for each of the six CEE countries. For example, the accumulated wealth of the optimal portfolio is around $\$ 30$ in December 2013; in contrast, the B\&H portfolio reaches less than $\$ 5$. We thus conclude that trading strategies based on our findings of the other month anomaly can potentially provide better returns than the passive B\&H market portfolios for investors in those CEE countries. 

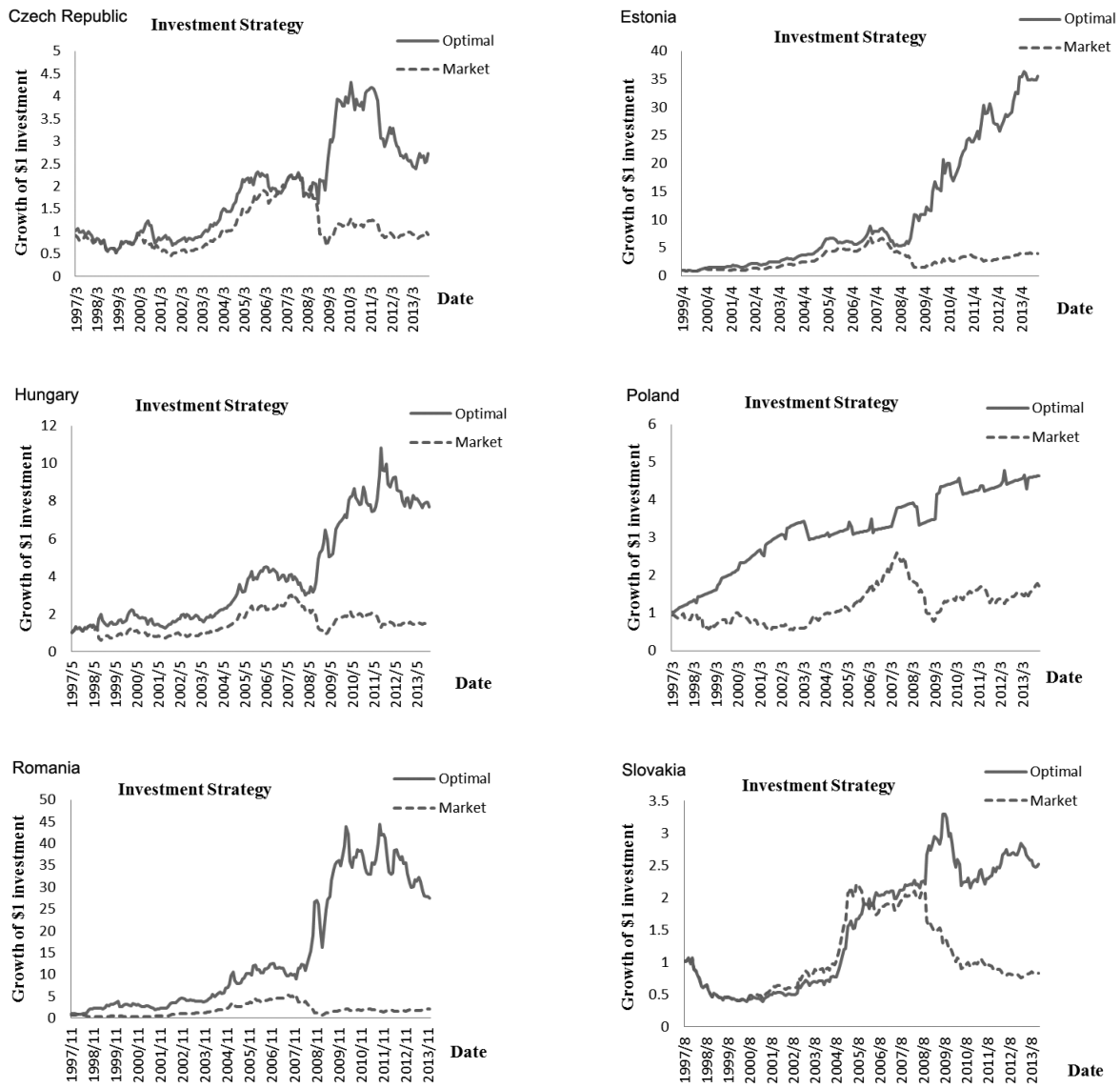

Figure 1. Accumulated wealth of $\$ 1$ investments on optimal portfolios $v s$. buy \& hold market portfolios

Notes: This figure presents the accumulated wealth of $\$ 1$ investments on the optimal portfolio $v s$. the benchmark portfolio (B\&H market portfolio) for each of six CEE countries over the period March 1997-December 2013 (except for Estonia which starts from 1999 due to lack of data). The investment strategies for the optimal portfolios are based on the other month effect that has the most significant return difference following positive and negative returns in the conditioning month (see Table 2). If the market return in the conditioning month is positive (negative), we long (short) the market portfolio for the next $N$ months and hold the risk-free asset in the conditioning month.

To further demonstrate the better performance of our optimal strategies, in Table 3 we report monthly geometric return, arithmetic return, risk and Sharpe Ratio on the optimal portfolio and the B\&H market portfolio for each country. The table shows that the arithmetic return and geometric return of the optimal portfolio in each country are significantly higher when compared with the $\mathrm{B} \& \mathrm{H}$ 
Table 3. Monthly geometric return, arithmetic return, risk and sharpe ratio for optimal and market portfolios

\begin{tabular}{lccccr}
\hline Country & $\begin{array}{c}\text { Investment } \\
\text { strategy }\end{array}$ & $\begin{array}{c}\text { Geometric } \\
\text { return }\end{array}$ & $\begin{array}{c}\text { Arithmetic } \\
\text { return }\end{array}$ & $\begin{array}{c}\text { Standard } \\
\text { deviation }\end{array}$ & Sharpe ratio \\
\hline Czech Republic & Optimal & 0.005 & 0.011 & 0.069 & 0.132 \\
& Market & 0.000 & 0.002 & 0.072 & -0.015 \\
Estonia & Optimal & 0.020 & 0.023 & 0.075 & 0.278 \\
& Market & 0.008 & 0.011 & 0.079 & 0.112 \\
Hungary & Optimal & 0.010 & 0.013 & 0.078 & 0.065 \\
& Market & 0.002 & 0.006 & 0.082 & -0.030 \\
Poland & Optimal & 0.008 & 0.008 & 0.031 & 0.020 \\
& Market & 0.003 & 0.005 & 0.073 & -0.028 \\
Romania & Optimal & 0.017 & 0.022 & 0.099 & 0.018 \\
& Market & 0.004 & 0.010 & 0.106 & -0.096 \\
Slovakia & Optimal & 0.005 & 0.006 & 0.057 & 0.020 \\
& Market & -0.001 & 0.001 & 0.059 & -0.072 \\
\hline
\end{tabular}

Notes: The optimal investment strategy is constructed to capture the other month effect based on the most significant month and holding period from Table 2 over the period 1997-2013. The benchmark is the buy-and-hold market portfolio. Geometric return and arithmetic return are calculated using monthly returns. The standard deviation of return can be viewed as a measure of risk. Sharpe ratio is the monthly average return (by subtracting the risk free rate) to its standard deviation.

portfolio. The optimal portfolios have lower volatility (standard deviation) than the B\&H portfolios. Table 3 also reveals that each optimal strategy has a higher Sharpe ratio than the B\&H portfolio, particularly in Estonia. Thus, these results present further evidence (in addition to Figure 1) of the superiority of our optimal investment strategies.

To summarise, we do not find the OJE in the six CEE stock markets, except for Slovakia. However, we identify some other month effects in those markets. Different markets have different other month effects, and those other month effects are only shown for some, but not all holding periods. The OJE is a predictive signal of returns for the remaining months when applied to the US stock market (Cooper et al. 2006). However, many recent studies conclude that the OJE cannot be generalised to other stock markets due to the different market characteristics (Easton - Pinder 2007; Darrat et al. 2013). The extant literature tends to refute the existence of the OJE, as pointed out by Marshall - Visaltanachoti (2010) and Chen - Daves (2013), and there are no conclusive explanations for the OJE. Nevertheless, Stivers et al. (2009) provide three possible explanations for the OJE, including an internationally priced risk factor, a ubiquitous behavioural bias and a temporary anomaly.

The OJE regarding the plausible explanation continues to be a subject of research controversy. Our results show significant anomalies for non-January 
months. This implies that investors can consider the high returns in other months instead of January. As mentioned above, we only discuss the possible factors behind the "other month" effect in the CEE markets. The CEE countries have faced remarkable changes from economic and political transformations through their accession to the European Union and capital market integration. The changes in the integration patterns and financial development levels do vary among all the EU countries (Kim et al. 2005). The degree of market efficiency in transition economies could affect the predictability of market returns or the profitability of trading strategies. Thus, our results may vary across the CEE countries due to the maturity of the capital market, the degree of financial integration, economic factors over stock returns, local risk factors, etc. On the other hand, we develop a trading rule using the other month effect to illustrate potential profitable investment strategies during the period from 1997 to 2013. We compare the accumulated wealth of $\$ 1$ investments at the beginning of the sample period on the optimal portfolio $v s$. the buy-and-hold market portfolio in each country. The investment strategies implementing optimal portfolios can enable investors to achieve higher returns than the passive investments in market portfolios.

\section{CONCLUSION}

The dictum "as goes January, so goes the rest of the year" refers to the alleged predictive power of market returns in January for the following 11 months. While Cooper et al. (2006) support the presence of the other January anomaly in the US stock market, a recent study shows stronger anomalies for non-January months as documented in Darrat et al. (2013). Marshall - Visaltanachoti (2010) suggest that the other January anomaly cannot be profitably implemented in any international market. This paper is motivated by the puzzle of the other January anomaly and thus to examine the "other month" effect.

The CEE countries have made significant economic and financial reforms with the European Union. Financial liberalisation and the degree of market efficiency in transition economies have an important impact on their stock markets. The uniqueness of transition economies in CEE allows us to gain some insights into whether the other month anomaly can provide useful information to investors in making profitable investment strategies.

Our paper investigates the other month anomaly (including the other January effect - OJE) in six CEE stock markets. We extend our analysis to holding period returns for 1-, 3-, 6-, and 11-month holding periods. Over the estimation period spanning from January 1991 to December 2013, the empirical results do not support the existence of the OJE in any of the CEE stock markets (the only exception 
being Slovakia). Consistent with Bohl - Salm (2010), Marshall - Visaltanachoti (2010), and Stivers et al. (2009), the OJE is not a common phenomenon to the US or any international markets. However, our results show anomalies in other months across markets. Further, we construct a trading rule based on our findings of the other month effect. For comparability across markets, all trading strategies are applied to the period of 1997 to 2013 on which data are available across all sampled countries. We compare the cumulative value of $\$ 1$ investments at the beginning of the sample period on our optimal portfolios $v s$. the passive buy-andhold market portfolios in each country. The results illustrate that optimal portfolios can be implemented by investors to earn abnormal returns.

Our paper has several important implications, but also some limitations. First, we find that the other month effect varies across markets, which might result from some potential factors such as the efficiency of market, local risk factors, and the practices of portfolio management for each country. Second, there are still no conclusive explanations for the OJE. Similarly, our results show significant anomalies for non-January months. The predictability for subsequent holding period returns based on the other month instead of January returns also remains a focus of research controversy. Thus, future research may continue to search for a plausible explanation for the puzzle of the other January/month effect. Finally, the CEE countries have achieved the transition and integration process in the European Union. The stock market environment has become more open to international investors. This implies an increase in the degree of linkages with several developed stock markets and thus the optimal trading strategy might also need to be revised. We leave those issues to future research.

\section{REFERENCES}

Asteriou, D. - Kavetsos, G. (2006): Testing for the Existence of the "January Effect" in Transition Economies. Applied Financial Economics Letters, 2(6): 375-381.

Bohl, M. T. - Salm, C. A. (2010): The Other January Effect: International Evidence. The European Journal of Finance, 16(1-2): 173-182.

Brown, L. - Luo, L. (2006): The January Barometer: Further Evidence. Journal of Investing, 15(1): 25-31.

Chen, Z. - Daves, P. (2013): The Index of Consumer Sentiment and the Other January Effect. Working Paper.

Cooper, M. J. - McConnell, J. J. - Ovtchinnikov, A. V. (2006): The Other January Effect. Journal of Financial Economics, 82(2): 315-341.

Cooper, M. J. - McConnell, J. J. - Ovtchinnikov, A. V. (2010): What's the Best Way to Trade Using the January Barometer? Journal of Investment Management, 8(4): 58-72.

Darrat, A. F. - Li, B. - Chung, R. (2013): The Other Month Effect: A Re-Examination of the "Other January" Anomaly. Review of Pacific Basin Financial Markets and Policies, 16 (2): 1-23. 
Darrat, A. F. - Li, B. - Liu, B. - Su, J. J. (2011): A Fresh Look at Seasonal Anomalies: An International Perspective. International Journal of Business and Economics, 10(2): 93-116.

Dzhabarov, C. - Ziemba, W. T. (2010): Do Seasonal Anomalies Still Work? Journal of Portfolio Management, 36(3): 93-104.

Easterday, K. E. - Sen, P. K. - Stephan, J. A. (2009): The Persistence of the Small Firm/January Effect: Is It Consistent with Investors' Learning and Arbitrage Efforts? The Quarterly Review of Economics and Finance, 49(3): 1172-1193.

Easton, S. A. - Pinder, S. M. (2007): A Refutation of the Existence of the Other January Effect. International Review of Finance, 7(3-4): 89-104.

Fama, E. (1970): Efficient Capital Markets: A Review of Theory and Empirical Work. Journal of Finance, 25(2): 383-417.

Fountas, S. - Segredakis, K. (2002): Emerging Stock Market Return Anomalies: The January Effect and the Tax-Loss Selling Hypothesis. Applied Financial Economics, 12(4): 291-299.

Gu, A. Y. (2003): The Declining January Effect: Evidence from the US Equity Markets. Quarterly Review of Economics and Finance, 43(2): 395-404.

Haugen, R. - Jorion, P. (1996): The January Effect: Still There after All These Years. Financial Analysts Journal, 52(1): 27-31.

Hensel, C. R. - Ziemba, W. T. (1995): The January Barometer. Journal of Investing, Summer: $67-70$.

Hirsch, Y. (1974): Stock Trader's Almanac. N.Y: The Hirsch Organization.

Ho, Y. (1990): Stock Return Seasonalities in Asia Pacific Markets. Journal of International Financial Management and Accounting, 2(1): 47-77.

Keim, D. B. (1983): Size-Related Anomalies and Stock Return Seasonality: Further Empirical Evidence. Journal of Financial Economics, 12(1): 13-32.

Kim, S. J. - Moshirian, F. - Wu, E. (2005): Dynamic Stock Market Integration Driven by the European Monetary Union: An Empirical Analysis. Journal of Banking and Finance, 29(10): 2475-2502.

Marshall, B. R. - Visaltanachoti, N. (2010): The Other January Effect: Evidence against Market Efficiency. Journal of Banking and Finance, 34(10): 2413-2424.

Mehdian, S. - Perry, M. J. (2002): Anomalies in US Equity Markets: A Re-Examination of the January Effect. Applied Financial Economics, 12(2): 141-145.

Rozeff, M. S. - Kinney, W. R. (1976): Capital Market Seasonality: The Case of Stock Returns. Journal of Financial Economics, 3(4): 379-402.

Stivers, C. - Sun, L. - Sun, Y. (2009): The Other January Effect: International, Style, and Sub Period Evidence. Journal of Financial Markets, 12(3): 521-546.

Tonchev, D. - Kim, T. H. (2004): Calendar Effects in Eastern European Financial Markets: Evidence from the Czech Republic, Slovakia and Slovenia. Applied Financial Economics, 14(14): $1035-1043$. 